DOI 10.18551/rjoas.2019-08.19

\title{
DEINDUSTRIALIZATION AMONG ASEAN COUNTRIES AND RELATED AFFECTING FACTORS
}

\author{
Sari Nilam Anggar*, Syahruddin, Lecturers \\ University of Kutai Kartanegara, Tenggarong, Indonesia \\ ${ }^{*}$ E-mail: nilamanggarsari@gmail.com
}

\begin{abstract}
This study aims to identify the causes of deindustrialization among ASEAN countries with years of analysis from 2000 to 2017 . Secondary data in this study were obtained from CEIC and the analysis method used an econometric model approach to panel data. The variable used to describe deindustrialization in this study (dependent variable) is manufacturing value added (MANVASUR) and the share of manufacturing in GDP (MANSHA). The results of the analysis show that per capita income, population, and economic openness have a significant effect on manufacturing value added (MANVASUR), while the share of manufacturing in GDP (MANSHA) is influenced by the wealth of natural resources, population, and economic openness. The population and per capita income of ASEAN member countries are positively related to the added value of the industrial sector, while economic openness is negatively related. This means that the more open the economy of a country, on the contrary the value added of the industrial sector actually decreases. Economic openness and natural resource wealth of ASEAN countries are positively related to the contribution (share) of the industrial sector to GDP, while the population is negatively marked by contribution (share) industrial sector to GDP. That means, the fewer the population, the less human resources involved in industry and industry will involve a lot of technology (capital intensive).
\end{abstract}

\section{KEY WORDS}

Deindustrialization, manufacturing, population, economic openness, income per capita.

As has happened in many developed countries, the process of transforming the economic structure has brought the success of quality economic growth (INDEF, 2017). The transformation of the economic structure here is the process of change from an agrarian economic structure to an industrial economic structure or also called industrialization. The opposite of industrialization is deindustrialization; Blackeby (1979) in Jalilian and Weiss (2000) states that deindustrialization is a decrease in the value added of the manufacturing sector or a decrease in the contribution of the manufacturing sector to national income. Deindustrialization in general is also experienced by countries in the world. The US in the late 1950s and Britain experienced de-industrialization since the 1970s. But in developed countries deindustrialization takes place as technology advances and innovations, so the contribution of the manufacturing industry to economic growth remains high (positive deindustrialization). Different situations experienced by developing countries. Rodrik (2015) revealed that developing countries experienced symptoms of deindustrialization without significant progress in the use of technology so that this condition was called negative deindustrialization.

The ASEAN economy is among the 7 largest in the world economy. The average economic growth of 10 ASEAN members in 2017 was estimated at $5 \%$, up from the previous year which reached $4.8 \%$. This condition exceeds global growth in 2017 which only reached $3.6 \%$. However, ASEAN faces challenges that have the potential to hinder its stated objectives; one of the causes is the presence of GDP per capita disparity among ASEAN member countries. The disparity is also caused by the different industrialization processes among ASEAN member countries. Data from the last 17 years among ASEAN countries shows that in 2000/2001, for example, the contribution of industry could reach $25-30 \%$ of GDP, but in 2017 the contribution reached a maximum of only $27 \%$. Indonesia, for example, experienced deindustrialization that was too early and the decline in its contribution was quite 
large at $10 \%$, Malaysia experienced a decline of $8 \%$, Singapore $7 \%$, and the Philippines $5 \%$. Some other countries have experienced a significant increase in contributions such as Myanmar, which in 2000 was only $7.2 \%$ in 2017 reaching $23.9 \%$. While countries like Laos and Cambodia, the contribution of the industrial sector to GDP is quite stable.

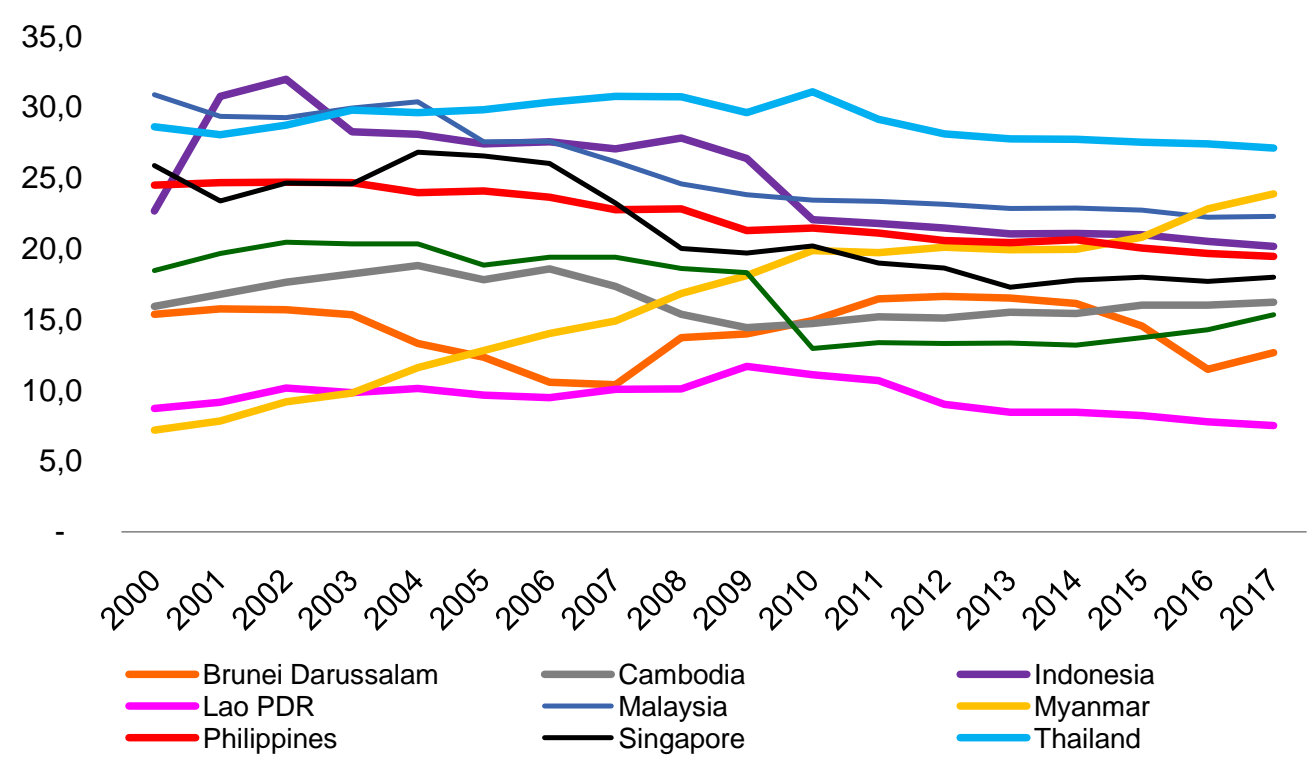

Figure 1 - Share of Manufacturing Value Added in GDP ASEAN Countries, \% (Source: CEIC, 2018)

The difference in the deindustrialization process among ASEAN members can lead to a gap in the acceleration of development in the Southeast Asia region. Thus the purpose of this study is to identify the causes of deindustrialization among ASEAN countries.

\section{METHODS OF RESEARCH}

The data used in this study comes from CEIC. The data type is panel data. According to Mudradjat (2011), the data panel is a combination of time series and cross-site data. In this research panel sample data used is 18 years from 10 ASEAN member countries, namely data from 2000 to 2017.

This study used two econometric model approaches to analyze the data, namely the panel regression analysis model with several independent variables and dependent variables. The variables used in the time series regression model are 4 independent variables consisting of Gross Domestic Product (GDP), population, exchange rate, and consumer price and 1 dependent variable is the number of passengers. The panel regression model uses 2 independent variables, namely the Gross Domestic Product (GDP) and the population, and passenger as the dependent variable.

Descriptive data basically only presents numerically the size of the mean, standard deviation, and distribution of a data. The statistical description of the variables used in this study is:

$$
\begin{aligned}
& \text { First Model: MANVASUR }=f(\text { GDPCPTCUR, POP, OPENCUR, EXPAGRI) } \\
& \text { Second Model: MANSHA }=f(\text { GDPCPTCUR, POP, OPENCUR, EXPAGRI) }
\end{aligned}
$$

Where: MANVASURES - Industrial Value Added (Manufactures Value Added) according to current prices (million US\$); MANSHA - Industrial Sector Share to GDP according to current price (\%); GDPCPTCUR - Per capita income with a proxy for Gross Domestic Product per capita according to current prices (US\$); POP - Total of Population; OPENCUR - Economic Openness with a proxy for export and import contributions to GDP current price (\%); 
EXPAGRI - Export of Agricultural Product Contribution to GDB current price (5); LNGDPCPTCUR - Natural Logarthm of the GDPCPTCUR Variable.

\section{RESULTS AND DISCUSSION}

Based on the structure of the first model (MANVACUR), in order to obtain the best panel regression estimation model, it is necessary to select an estimation model between Pooled Least Squares (PLS), Fixed Effect (FE) and Random Effect (RE) models. The selection of the estimation model uses the Chow Test, Breusch and Pagan Results of the Lagrangian Multiplier Test, and the Haussman Test where a summary of the comparisons between models can be seen in table 1 .

Table 1 - Comparison between FE, RE, and PLS Models

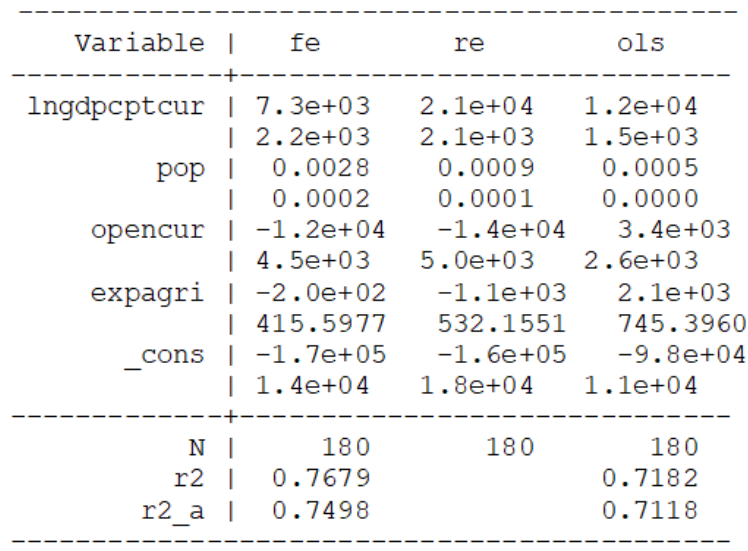

Legend: b/se

Based on the summary of the model, FE model has adjusted R2 (r2-a) greater than PLS, which is equal to 0.7498 . This means that per capita income (GDPCPTUR), population (POP), economic openness (OPENCUR) and natural resource wealth (EXPAGRI) are able to explain the Value Added of the Industrial Sector (MANVACUR) of 74.98 percent and the rest explained by other factors outside the model. Based on the results of the suitability testing of the model, the appropriate model to explain Manufacture Value Added in ASEAN is Fixed Effect (Table 2). Just like in the normal liner regression, in panel data regression the result also needs to be evaluated. The stages of evaluating the results carried out include:

Table 2 - Fixed Effect Model Output

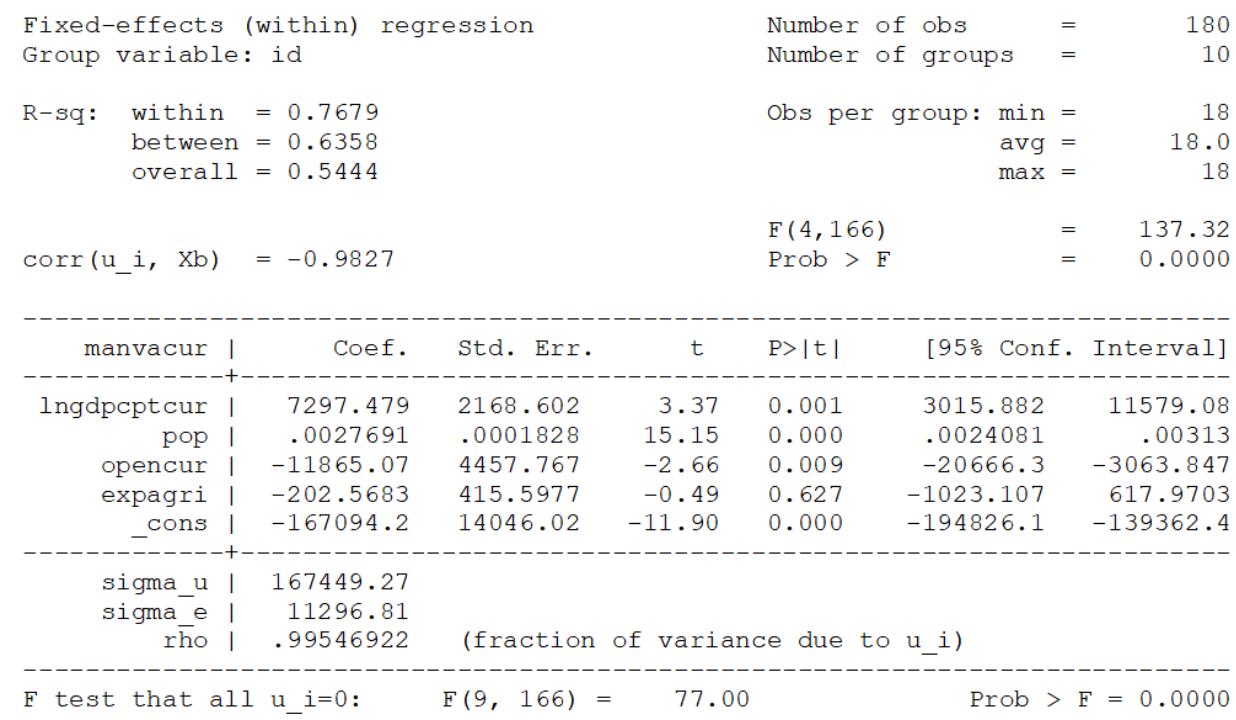


Testing the assumption of the regression model, first of all, the error of the model must be normally distributed, the variance is constant (homoscedasticity), there is no multicollinearity between the independent variables and no autocorrelation occurs. According to Baltagi (1981), the basis of forming a panel model still uses Least Square. Therefore, in evaluating the results of the simultaneous-panel equation model can be done through the Least Square approach. For the random effects (RE) model the estimation method used is Generalized Least Square (GLS). So in the RE model there is no need for heteroscedasticity and autocorrelation testing. Based on the selection of the model above, the Fixed Effect (FE) model is chosen, so all three assumptions of the model must be done. The results of testing the classical assumptions violate the assumption of the absence of multicollinearity but there are heteroscedasticity and autocorrelation so to overcome violations in the Fixed Effect model estimation models are used with General Least Squared (GLS) (Table 3).

Table 3 - Fixed Effect Model Output with GLS

\begin{tabular}{|c|c|c|c|c|c|c|c|}
\hline \multicolumn{8}{|c|}{$\begin{array}{ll}\text { Panels: } & \text { homoskedastic } \\
\text { Correlation: } & \text { no autocorrelation }\end{array}$} \\
\hline \multicolumn{3}{|c|}{ Estimated covariances } & \multicolumn{2}{|l|}{$=$} & \multicolumn{2}{|c|}{ Number of obs = } & 180 \\
\hline \multirow{2}{*}{\multicolumn{3}{|c|}{ Estimated autocorrelations }} & \multicolumn{2}{|c|}{0} & \multicolumn{2}{|c|}{ Number of groups $=$} & 10 \\
\hline \multirow{2}{*}{\multicolumn{3}{|c|}{ Estimated coefficients }} & \multicolumn{2}{|l|}{14} & Time periods & iods $\quad=$ & \\
\hline & & & \multirow{2}{*}{\multicolumn{2}{|c|}{$=-1927.931$}} & \multirow{2}{*}{\multicolumn{2}{|c|}{$\begin{array}{l}\text { Wald chi2 (13) } \\
\text { Prob > chi2 }\end{array}$}} & 3125.39 \\
\hline \multicolumn{3}{|c|}{ Log likelihood } & & & & & 0.0000 \\
\hline manvacur & I & Coef. & std. Err. & z & $\mathrm{P}>|z|$ & [95\% Conf. & Interval] \\
\hline lngdpcptcur & I & 7297.479 & 2082.561 & 3.50 & 0.000 & 3215.734 & 11379.22 \\
\hline pop & i & .0027691 & .0001756 & 15.77 & 0.000 & .0024249 & .0031132 \\
\hline opencur & i & -11865.07 & 4280.9 & -2.77 & 0.006 & -20255.48 & -3474.663 \\
\hline expagri & l & -202.5683 & 399.1085 & -0.51 & 0.612 & -984.8066 & 579.67 \\
\hline & i & & & & & & \\
\hline id & i & & & & & & \\
\hline 2 & i & -6872.406 & 10791.3 & -0.64 & 0.524 & -28022.96 & 14278.14 \\
\hline 3 & i & -511842.7 & 45592.49 & -11.23 & 0.000 & -601202.4 & -422483.1 \\
\hline 4 & I & 6543.587 & 8894.621 & 0.74 & 0.462 & -10889.55 & 23976.72 \\
\hline 5 & I & -4392.738 & 9260.775 & -0.47 & 0.635 & -22543.52 & 13758.05 \\
\hline 6 & i & -111712.9 & 15906.94 & -7.02 & 0.000 & -142889.9 & -80535.85 \\
\hline 7 & i & -196925.6 & 20403.5 & -9.65 & 0.000 & -236915.8 & -156935.5 \\
\hline 8 & i & 57726.58 & 12354.45 & 4.67 & 0.000 & 33512.32 & 81940.85 \\
\hline 9 & I & -83544.69 & 15849.22 & -5.27 & 0.000 & $-114608 \cdot 6$ & -52480.8 \\
\hline 10 & I & -195443.7 & 21580.72 & -9.06 & 0.000 & -237741.2 & -153146.3 \\
\hline & I & & & & & & \\
\hline _cons & I & -62447.75 & 21152.95 & -2.95 & 0.003 & -103906.8 & -20988.73 \\
\hline
\end{tabular}

Feasibility Test Model includes Overall Test (F-test), Partial Test (t-test) and Goodness of Fit Test (coefficient of determination). The Goodness of fit test is used to measure how much variation in the value of dependent variables can be explained by variations in the value of the independent variable. This test is done by looking at R-squared from the estimated regression results. As with simple R-squared regression models it is useful to see the ability of independent variables to explain dependent variables. In the fixed effect model there are three types of R-squared, namely within, between regions (between) and the whole (overall). Based on Table 2 (Fixed Effect), it can be seen that the R-square value of within, between and overall is quite large. Sequentially the R-square within value is 0.7679 (76.79 percent), the R-square between is 0.6358 (63.58 percent) and the R-square overall is 0.5444 (54.44 percent). R-Square within 0.7679 means that the value added of the industrial sector in ASEAN member countries is able to be explained by the model of 76.79 percent and the rest is explained by other variables outside the model. The R-Square between 0.6358 means that the value added of the industrial sector among ASEAN member countries is only able to be explained by the model of 63.58 percent and the rest is explained by other independent variables outside the model. Then the $\mathrm{R}$-square overall is 0.5444 which means that overall the value added of the industrial sector of ASEAN member countries is explained by the model of 54.44 percent and the rest is explained by other independent variables outside the model.

Table 2 is the provisional result of the fixed effect model with the OLS estimation method. Based on the table, it can be seen that $F$ count is 137.32 or Prob> F is 0.0000 . 
Because the calculated $\mathrm{F}$ value is greater than $\mathrm{F}$ table or a significant value smaller than $\alpha=$ 1 percent $(0,000<\alpha)$ then $\mathrm{Ho}$ is rejected or accepts $\mathrm{H}_{1}$. This means that simultaneously the per capita income (GDPCPTCUR), population (POP), economic openness (OPENCUR) and natural resource wealth (EXPAGRI) have a significant effect on the added value of the industrial sector (MANVACUR). This shows that the independent variables used in this study are clear explanations on dependent variables and also show that the model is feasible to use.

Partial test is used to find out the effect of partial variables partially significantly (real) effect on dependent variables. To find out the results of the partial test can be seen from the $t$-value calculated or the value $P>|t|$ If the $t$-value is greater than $t$-table or $P>|t|$ smaller than $\alpha=1$ percent, so the independent variable is significant in explaining dependent variables. Based on Table 3 above, the value of $P>|t|$ of the two independent variables the value is 0.000 or more than $\alpha=1$ percent. This means that per capita income, population, and economic openness have a significant effect on the value added of the industrial sector, while natural resource wealth does not affect it. Based on Table 2, there has been a violation of the assumption that there is no autocorrelation and heteroscedasticity, so that it is overcome by the GLS estimation method. Estimated results with GLS do not affect the results of the feasibility test model.

Based on model selection and model evaluation, it was found that the model suitable for panel data in this analysis was Fixed Effect Model with GLS estimation method. The regression output of the Fixed Effect model with the GLS estimation method as shown in Table 3. From Table 3, it can be seen that the independent variable per capita income (GDPCPTCUR), population (POP), and economic openness (OPENCUR) have a significant effect on industrial sector value added (MANVACUR). The regression model above can be written in the econometric equation as follows:

$$
\begin{aligned}
\text { MANVACUR }_{i t}= & I D_{i d}-62.447,75+7.297,479\left(\text { LNGDPCPTCUR }_{i t}\right)+0,0027691\left(\text { POP }_{i t}\right)- \\
& 11.865,07\left(\operatorname{OPENCUR}_{i t}\right)-202,5683\left(\operatorname{EXPAGRI}_{i t}\right)+v_{i t}
\end{aligned}
$$

ID variable is the location of 10 ASEAN member countries with different values according to location. The above model indicates that the independent variable income per capita (GDPCPTCUR), population (POP), and economic openness (OPENCUR) have a significant effect on the added value of the industrial sector (MANVACUR). From the independent variables that have a significant effect the coefficient is varied. The number of population and income per capita are positive. This provides an explanation that the more the population increases and the per capita income of ASEAN member countries increases, the added value of the industrial sector will also increase assuming the other variables are constant or vice versa. Then the coefficient of economic openness is negative, meaning that the more open the economy of a country, on the contrary the value added of the industrial sector actually decreases. Furthermore, natural resource wealth (EXPAGRI) has no effect on changes in the value added of the industrial sector.

The above model can be written according to each country and the difference is only in the intercept. The following models are presented according to ASEAN member countries.

Brunei Darussalam:

MANVACUR $_{i t}-62.447 .75+7.297,479\left(L_{N G D P C P T C U R} i t\right)+0,0027691\left(P O P_{i t}\right)-11.865,07\left(\right.$ OPENCUR $\left._{i t}\right)-202,5683\left(\right.$ EXPAGRI $\left._{i t}\right)+v_{i t}$

Cambodia:

MANVACUR $_{i t}-69.320,16+7.297,479\left(\operatorname{LNGDPCPTCUR}_{i t}\right)+0,0027691\left(P_{0} P_{i t}\right)-11.865,07\left(\right.$ OPENCUR $\left._{i t}\right)-202,5683\left(\right.$ EXPAGRI $\left._{i t}\right)+v_{i t}$

Indonesia:

MANVACUR $_{i t}-574.290,45+7.297,479\left(L_{N G D P C P T C U R} i t\right)+0,0027691\left(P_{i t} P_{i t}\right)-11.865,07\left(\operatorname{OPENCUR}_{i t}\right)-202,5683\left(\mathrm{EXPAGRI}_{i t}\right)+v_{i t}$

Laos:

MANVACUR $_{i t}-55.904,16+7.297,479\left(L_{N G D P C P T C U R} i t\right)+0,0027691\left(P_{0 P} i t\right)-11.865,07\left(\right.$ OPENCUR $\left._{i t}\right)-202,5683\left(\mathrm{EXPAGRI}_{i t}\right)+v_{i t}$ 
Malaysia:

MANVACUR $_{i t}-66.840,49+7.297,479\left(L_{N G D P C P T C U R} i t\right)+0,0027691\left(P_{0 P} P_{i t}\right)-11.865,07\left(\right.$ OPENCUR $\left._{i t}\right)-202,5683\left(\operatorname{EXPAGRI}_{i t}\right)+v_{i t}$

Myanmar:

MANVACUR $_{i t}-174.160,65+7.297,479\left(L_{N G D P C P T C U R} i t\right)+0,0027691\left(P_{i t} P_{i t}\right)-11.865,07\left(\right.$ OPENCUR $\left._{i t}\right)$ $-202,5683\left(\right.$ EXPAGRI $\left._{i t}\right)+v_{i t}$

Philippines:

MANVACUR $_{i t}-259.373,35+7.297,479\left(\right.$ LNGDPCPTCUR $\left._{i t}\right)+0,0027691\left(\right.$ POP $\left._{i t}\right)-11.865,07\left(\right.$ OPENCUR $\left._{i t}\right)-202,5683\left(\operatorname{EXPAGRI}_{i t}\right)+v_{i t}$

Singapore:

MANVACUR $_{i t}-4.721,17+7.297,479\left(L_{N G D P C P T C U R} i t\right)+0,0027691\left(P_{0} P_{i t}\right)-11.865,07\left(\right.$ OPENCUR $\left._{i t}\right)-202,5683\left(\operatorname{EXPAGR}_{i t}\right)+v_{i t}$

Thailand:

MANVACUR $_{i t}-145.992,44+7.297,479\left(\right.$ LNGDPCPTCUR $\left._{i t}\right)+0,0027691\left(\right.$ POP $\left._{i t}\right)-11.865,07\left(\right.$ OPENCUR $\left._{i t}\right)-202,5683\left(\operatorname{EXPAGRI}_{i t}\right)+v_{i t}$

Vietnam:

MANVACUR $_{i t}-257.891,45+7.297,479\left(\right.$ LNGDPCPTCUR $\left._{i t}\right)+0,0027691\left(\right.$ POP $\left._{i t}\right)-11.865,07\left(\right.$ OPENCUR $\left._{i t}\right)-202,5683\left(\right.$ EXPAGRI $\left._{i t}\right)+v_{i t}$

The slope values of all countries are the same, but the intercept value varies between countries. Among the ASEAN member countries, Indonesia has the highest negative intercept, which is $574,290.45$. This value implies an understanding that industrial sector added value will decrease by $574,290.45$ million US $\$$ if per capita income, population, economic openness, and export of natural resource. This is understandable because the main industrial raw material in Indonesia comes from the agricultural sector natural resources (EXPAGRI), if more and more Indonesian natural resources are exported it will minimize added value from the industrial sector. While the smallest negative intercept value is owned by Singapore, which only reaches $4,721.17$. The small condition of Singapore's intercept value is in line with the advanced economic conditions among ASEAN countries.

Based on the structure of the second model (MANSHA), in order to obtain the best panel regression estimation model, it is necessary to select an estimation model between the Pooled Least Squares (PLS) model, Fixed Effect (FE) and Random Effect (RE). The selection of the estimation model uses the Chow Test, Breusch and Pagan Results of the Lagrangian Multiplier Test, and the Haussman Test where a summary of the comparisons between models can be seen in Table 4 below.

Table 4 - Inter-Model Comparison (MANSHA)

\begin{tabular}{|c|c|c|c|}
\hline Variable & $\mathrm{FE}$ & $\mathrm{RE}$ & PLS \\
\hline $\begin{array}{r}\text { Ingdpcptcur } \\
\text { pop } \\
\text { opencur } \\
\text { expagri } \\
\text { C }^{\text {cons }}\end{array}$ & $\begin{array}{r}-0.6189 \\
0.4517 \\
-0.0000 \\
0.0000 \\
5.1383 \\
0.9286 \\
0.3491 \\
0.0866 \\
26.4595 \\
2.9259\end{array}$ & $\begin{array}{r}-1.6597 \\
0.3801 \\
-0.0000 \\
0.0000 \\
5.3900 \\
0.8953 \\
0.4224 \\
0.0889 \\
25.8648 \\
3.4051\end{array}$ & $\begin{array}{l}0.4491 \\
0.3167 \\
0.0000 \\
0.0000 \\
2.6963 \\
0.5373 \\
0.5438 \\
0.1535 \\
8.8290 \\
2.3094\end{array}$ \\
\hline $\begin{array}{r}\mathrm{N} \\
\mathrm{r} 2 \\
\mathrm{r} 2 \mathrm{a}\end{array}$ & $\begin{array}{r}180 \\
0.3802 \\
0.3317\end{array}$ & 180 & $\begin{array}{r}180 \\
0.3673 \\
0.3528\end{array}$ \\
\hline
\end{tabular}

legend: $\mathrm{b} / \mathrm{se}$ 
Based on the summary of the model, model FE has adjusted R2 ( $\mathrm{r} 2-\mathrm{a})$ smaller than PLS, which is equal to 0.3317. Although the PLS Model has bigger adjusted R2 (r2-a) value, but in model testing the most suitable model is FE, that is why the model used is Fixed Affect Model. Adjusted R2 (r2-a) value of 0.3317 means that per capita income (GDPCPTUR), population (POP), economic openness (OPENCUR) and natural resource wealth (EXPAGRI) are able to explain the Industrial Sector Share to the economy (MANSHA) of 33, 17 percent and the rest explained by other factors outside the model. Based on the results of the suitability of the model above, the appropriate model to explain the Industrial Sector Share of the economy in the ASEAN member countries is Fixed Effect.

Table 5 - Output of Fixed Effect Model

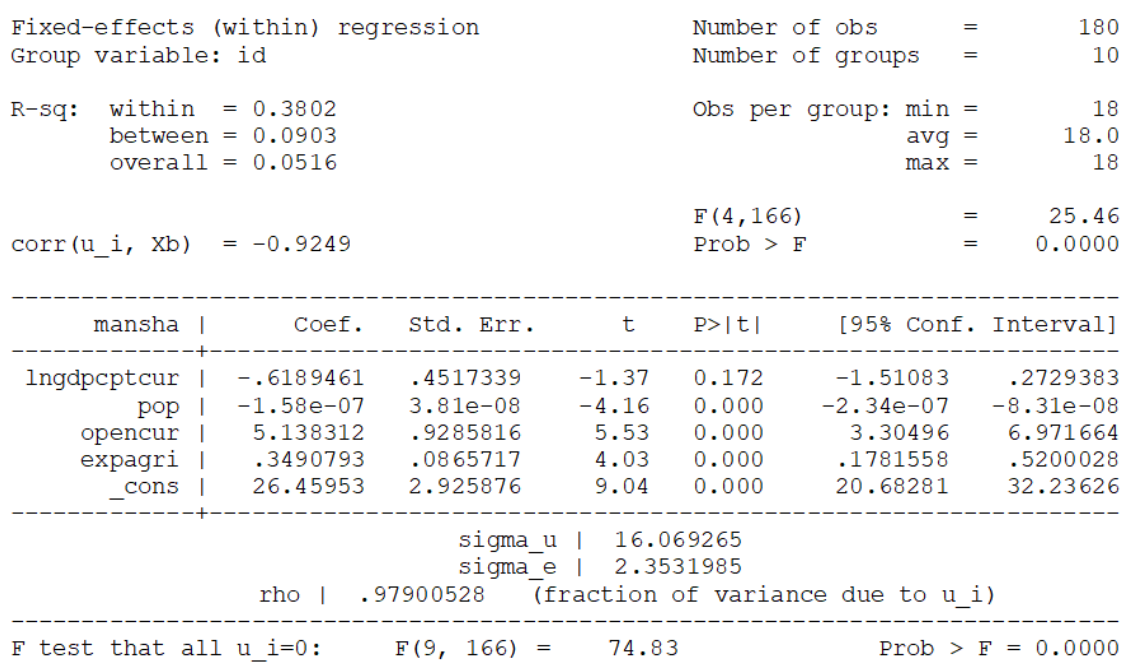

Based on the selection of the Industrial Sector Share model on GDP above the appropriate model is Fixed Effect and the results of testing the classical assumption occur violation of assumptions namely the existence of heteroscedasticity and the existence of autocorrelation so to overcome violations in the Fixed Effect model, Estimation models with General Least Squared (GLS) was used.

Table 6 - Output of Fixed Effect Model with GLS

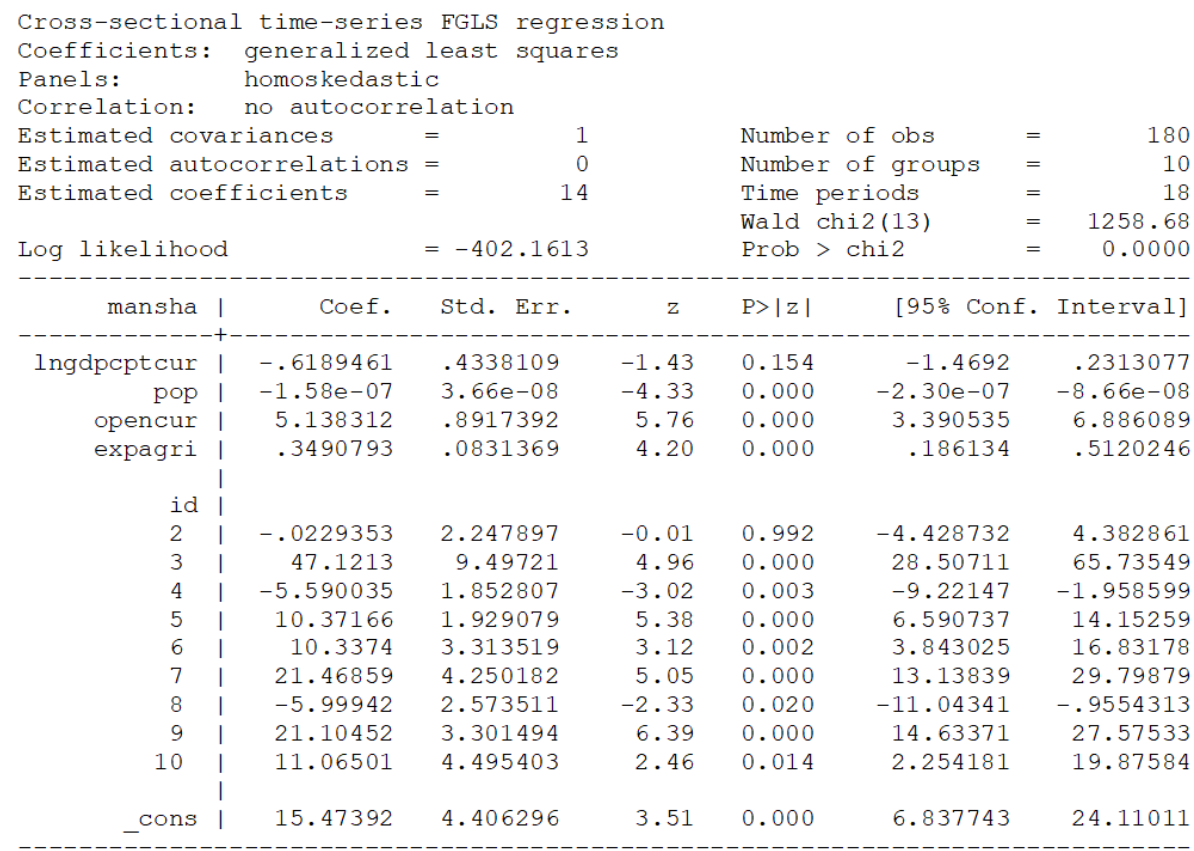


The feasibility test of the model in the panel data model uses the $F$ test (overall test), $t$ test (partial test) and goodness of fit test. As with ordinary linear regression models, the $F$ test (overall test) is used to test the feasibility of a regression model as a whole, meanwhile $T$ test used to answer problems, achieve goals and prove hypotheses. T Test (Partial test) also used to determine whether the independent variables partially have a significant effect (real) to dependent variables. The Goodness of fit test is used to measure how much variation in the value of dependent variables can be explained by variations in the value of the independent variable. This test is done by looking at R-squared from the estimated regression results. As with simple R-squared regression models, it is useful to see the ability of independent variables to explain dependent variables. In the fixed effect model there are three types of R-squared, namely within, between and overall.

Based on Table 5, it can be seen that the R-square value of within, between and overall is relatively small. It is probably due to the few observation series. Sequentially the within R-square the value is 0.3802 (38.02 percent), the between R-square is 0.0903 (9.03 percent) and the overall $R$-square is 0.0516 (5.16 percent). With the within R-Square 0.3802 means that the Industrial Sector Share of GDP in ASEAN member countries is only able to be explained by the model of 38.02 percent and the rest is explained by other variables outside the model. And then between R-Square 0.0903 means that the Industrial Sector Share of GDP among ASEAN member countries is only able to be explained by the model of 9.03 percent and the rest is explained by other independent variables outside the model. Then the overall R-square of 0.0516 implies that the whole Industrial Sector Share of the GDP of ASEAN member countries is only able to be explained by the model of 5.16 percent and the rest explained by other independent variables outside the model. Table 5 is the provisional result of the fixed effect model with the OLS estimation method. Based on the table, it can be seen that $F$ count is 25.46 or Prob> F is 0.0000 . Because the calculated $F$ value is greater than $F$ table or a significant value smaller than $\alpha=1$ percent $(0,000<\alpha)$ then $\mathrm{Ho}$ is rejected or in other word $\mathrm{H} 1$ is accepted. This means that simultaneously the per capita income (GDPCPTCUR), population (POP), economic openness (OPENCUR) and natural resource wealth (EXPAGRI) have a significant effect on the Industrial Sector Share of GDP (MANSHA). This indicates that the independent variables used in this research is a clear explanation on dependent variables and also shows that the model is feasible to use.

Partial test is used to find out the effect of independent variables partially significantly (real) effect on dependent variables. To find out the results of the partial test can be seen from the t-value calculated or the value $P>|t|$ If the $t$-value is greater than t-table or $P>|t|$ smaller than $\alpha=1$ percent, the independent variable is significant in explaining dependent variables. Based on Table 5 above, the value of $P>|t|$ of the two independent variables, the value is 0,000 or smaller than $\alpha=1$ percent. This means that the population, economic openness and natural resource wealth have a significant effect on the Industrial Sector Share of GDP, while per capita income does not affect it. Based on Table 5 there has been a violation of assumptions, namely the existence of autocorrelation and heteroscedasticity, so that it is overcome by the GLS estimation method. Estimated results with GLS do not affect the results of the model feasibility test.

Based on model selection and model evaluation, it was found that the model suitable for panel data in this analysis was Fixed Effect Model with GLS estimation method. The regression output of the Fixed Effect model with the GLS estimation method as shown in Table 6. From Table 6 it can be seen that the independent variables, population (POP), economic openness (OPENCUR), and natural resource wealth (EXPAGRI) have a significant effect on the Share of Industrial Sector GDP (MANSHA). The regression model above can be written in the econometric equation as follows:

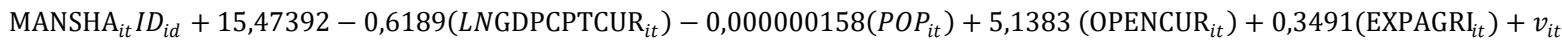

ID variable is the location of 10 ASEAN member countries with different values according to location. The model above implies that the independent variable population number (POP), economic openness (OPENCUR) and natural resource wealth (EXPAGRI) 
have a significant effect on the Industrial Sector Share of GDP (MANSHA). From the independent variables that have a significant effect the coefficient is varied. Coefficient's economic openness and natural resource wealth are positive. This provides an explanation that the more open the economy and the increasing natural resource wealth of ASEAN member countries, the contribution (share) of the industrial sector to GDP will also be greater assuming other variables are constant or also vice versa. And then the coefficient of population number is negative, it means the more the population in a country, then the contribution (share) of industrial sector to GDP decreases or conversely the fewer the population, the greater the industrial sector share of GDP. This can be understood because the fewer the population, the less human resource will be used and the industry will be more capital intensive. Furthermore, per capita income does not affect the change in value added of the industrial sector.

As with the model of industrial value added, this model can be written according to each country and differences only in its intercept. The following models are presented according to ASEAN member countries.

Brunei Darussalam:

MANSHA $_{i t}=15,4739-0,6189\left(L_{N G D P C P T C U R} i t\right)-0,000000158\left(P O P_{i t}\right)+5,1383\left(\operatorname{OPENCUR}_{i t}\right)+0,3491\left(\operatorname{EXPAGRI}_{i t}\right)+v_{i t}$

Cambodia:

MANSHA $_{i t}=15,4510-0,6189\left(\right.$ LNGDPCPTCUR $\left._{i t}\right)-0,000000158\left(P_{O P} P_{i t}\right)+5,1383\left(\right.$ OPENCUR $\left._{i t}\right)+0,3491\left(\right.$ EXPAGRI $\left._{i t}\right)+v_{i t}$

Indonesia:

MANSHA $_{i t}=62,5952-0,6189\left(L_{N G D P C P T C U R} i t\right)-0,000000158\left(P_{0 P} P_{i t}\right)+5,1383\left(\right.$ OPENCUR $\left._{i t}\right)+0,3491\left(\right.$ EXPAGR $\left._{i t}\right)+v_{i t}$

Laos:

MANSHA $_{i t}=9,8839-0,6189\left(L_{N G D P C P T C U R} i t\right)-0,000000158\left(P_{i t}\right)+5,1383\left(\operatorname{OPENCUR}_{i t}\right)+0,3491\left(\operatorname{EXPAGRI}_{i t}\right)+v_{i t}$

Malaysia:

MANSHA $_{i t}=25,8456-0,6189\left(L_{N G D P C P T C U R} i t\right)-0,000000158\left(P_{0} P_{i t}\right)+5,1383\left(\right.$ OPENCUR $\left._{i t}\right)+0,3491\left(\operatorname{EXPAGRI}_{i t}\right)+v_{i t}$

Myanmar:

MANSHA $_{i t}=25,81132-0,6189\left(L_{N G D P C P T C U R} i t\right)-0,000000158\left(P O P_{i t}\right)+5,1383\left(\right.$ OPENCUR $\left._{i t}\right)+0,3491\left(\right.$ EXPAGRI $\left._{i t}\right)+v_{i t}$

Philippine:

MANSHA $_{i t}=36,94251-0,6189\left(L_{N G D P C P T C U R}\right)-0,000000158\left(P_{i t} O P_{i t}\right)+5,1383\left(\right.$ OPENCUR $\left._{i t}\right)+0,3491\left(\right.$ EXPAGRI $\left._{i t}\right)+v_{i t}$

Singapore:

MANSHA $_{i t}=9,4745-0,6189\left(L_{N G D P C P T C U R}\right)-0,000000158\left(P O P_{i t}\right)+5,1383\left(\right.$ OPENCUR $\left._{i t}\right)+0,3491\left(\operatorname{EXPAGRI}_{i t}\right)+v_{i t}$

Thailand:

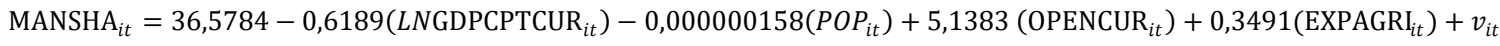

Vietnam:

MANSHA $_{i t}=26,5389-0,6189\left(L_{N G D P C P T C U R} i t\right)-0,000000158\left(P_{0 P}\right)+5,1383\left(\right.$ OPENCUR $\left._{i t}\right)+0,3491\left(\right.$ EXPAGRI $\left._{i t}\right)+v_{i t}$

The slope values of all countries are the same, but the intercept value varies between countries. Among these ASEAN member countries, Indonesia has the largest intercept, 
which is equal to 62,5952 . This value means that the industrial sector share of Indonesia's GDP will remain at $62.5952 \%$ assuming per capita income, population, economic openness, and exports of natural resource wealth unchanged. While the smallest intercept value is owned by Singapore, which only reaches $9.4745 \%$. The small condition of Singapore's intercept means that Singapore's economy is highly dependent on the contribution of the Manufacturing Industry Sector. If the factors that influence the contribution of the manufacturing sector do not change, so the contribution of manufacturing will be relatively small compared to other countries in ASEAN. This is because Singapore is one of the hightech manufacturing exporters and has a significant impact on the Asia Pacific manufacturing industry.

\section{CONCLUSION}

Based on the selection of the model, the appropriate model to explain the factors that influence the added value and the contribution of the industrial sector to GDP is the Fixed Effect Model Panel.

Per capita income, population, and economic openness have a significant effect on the added value of the industrial sector. While the contribution of the industry sector to GDP is influenced by the wealth of natural resources, population, and economic openness.

The population and per capita income of ASEAN member countries are positively related to the added value of the industrial sector, while economic openness is negatively related. This means that the more open the economy of a country, on the contrary the value added of the industrial sector actually decreases.

Economic openness and natural resources of ASEAN countries are positively related to the contribution (share) of the industrial sector to GDP, while the population is negatively marked by the contribution (share) of the industrial sector to GDP. That means, the fewer the population, the less human resources involved in industry and industry will involve a lot of technology (capital intensive).

\section{REFERENCES}

1. Alderson, A. 1997. Globalization and Deindustrialization: Direct Investment and the Decline of Manufacturing Employment in 17 OECD Nations. Journal of World-System Research. Vol 3(1):1-34

2. Andriyani, V.E., 2018. Identification of Premature Deindustrialization and Its Acceleration in Indonesia (Peruod 1986-2015). Jurnal Ekonomi dan Kebijakan Pembangunan 78-101.

3. Asyraf, T.M. 2019. Is Malaysia Experiencing Premature Deindustrialization? BNM Quarterly Bulletin.

4. Baltagi, B.H. 2005. Econometric Analysis of Panel Data. John Wiley \& Sons LTD.

5. Dasgupta S, Singh A. 2005. Will Services be the New Engine of Indian Economic Growth? Journal of Development and Change Institute of Social Studies 36:1035-1057.

6. Dasgupta, S. 2006. Manufacturing, Services and Premature Deindustrialization in Developing Countries: A Kaldorian Analysis. United Nation University No 2006/49: 1-18

7. Dewi,D.A. 2010. Deindustrialisasi di Indoensia 1983-2008: Analisis Dengan Pendekatan Kaldorian (tesis). Bogor: Program Pascasarjana, Institut Pertanian Bogor.

8. Jalilian H, Weiss J. 2000. Deindustrialization in Sub Saharan: Myth or Crysis? Journal of American Economies Volume 9 Number 1: 24-43.

9. Kassem, D. 2010. Premature Deindustrialization-The Case of Colombia. Discussion Paper Series. Yokohama National University. No 2010-CSEG-06

10. Rodrik, D. Premature Deindustrialization. J. Econ Growth. DOI 10.1007/s10887-0159122-3.

11. Rowthorn, R. 1992. Productivity and American Leadership-A Review. Review of Income and Wealth Vol.38, No 4:47-96.

12. Suwarman, W. 2006. Faktor-faktor apakah yang Mendorong Terjadinya Proses Deindustrialisasi di Indonesia. Program Pascasarjana, Universitas Indonesia. 